\title{
Lignans from The Nepalese Sandal Wood Osyris wightiana Wall ex Wight
}

\author{
Sajan L Shyaula ${ }^{* 1}$, Mangala D Manandhar ${ }^{1}$, M. I. Choudhary ${ }^{2}$ \\ ${ }^{1}$ Faculty of Science, Nepal Academy of Science and Technology, Khumaltar, Lalitpur, Nepal, ${ }^{2}$ H.E.J. \\ Research Institute of Chemistry, International Center for Chemical and Biological Sciences, University of \\ Karachi, Karachi-75270, Pakistan; Email: shyaulasajan@gmail.com
}

\begin{abstract}
The crude ethanolic extract of the Nepalese sandal wood, Osyris wightiana Wall ex Wight, was investigated for phytochemical constituents by chromatographic and spectroscopic techniques. The lignans were the first time reported from the genus Osyris. The lignans, ( \pm ) lyoniresinol (1), ( \pm ) syringaresinol (2) 5,5'-dimethoxylariciresinol (3), and 5-methoxylariciresinol (4) were isolated from dichloromethane fraction. The structures of compounds were identified by using mass and NMR spectroscopic techniques.
\end{abstract}

Keywords: Osyris wightiana, lignans

\section{Introduction}

Osyris wightiana Wall ex Wight belongs to family santalaceae. It is widely distributed in the tropical and temperate zones at the altitudes of 900 to 2,500 $\mathrm{m}$ from Simla to Bhutan, Myanmar, India, Nepal and China. ${ }^{1}$ It is a shrub, about 2-3 m tall and locally known as 'Nundhiki' in central Nepal. ${ }^{2}$ It is used as a wild herbal tea, in Kavre district of Nepal. The tea made from the leaves of $O$. wightiana stimulates the flow of breast milk and also acts as a labor inducing agent. ${ }^{3}$ A root paste is plastered around the fractured bone after adjusting it properly. ${ }^{4}$ The root bark is boiled in water about 10 minutes, cooled, stressed and the liquid, about 10 teaspoons three times a day, is given to a women after child birth to stop bleeding. ${ }^{5}$

Most of the plants belonging to family, santalaceae have strong characteristic fragrance and are known for its volatile constituents. Previous phytochemical studies on genus Osyris has yielded hexyl and hexenyl derivatives, sesquiterpenes, phenolic acids, flavoinoids, pyrrolizidine and quinolizidine alkaloids, long chain hydrocarbons and fattyacids, triterpenes, dihydro- $\beta$-agarofuran sesquiterpenes, phenolics and phenyl propanoids. ${ }^{6-14}$ On present phytochemical investigation of Nepalese sandal wood, $O$. wightiana collected from central Nepal, lignans class of compounds are isolated and identified by using modern spectroscopic techniques. This is the first report demonstrating the presence of lignans in the genus Osyris. The results indicate the possible chemotaxonomic significance of the occurrence of lignans in santalaceae.

\section{Experimental}

General

Melting points were recorded on a Yanaco MP-S3 apparatus. Optical rotations were measured on JASCO DIP-360 digital polarimeter. UV spectra were measured on a Shimazdu UV 240

\footnotetext{
* Corresponding author
} 
spectrophotometer. The IR spectra recorded on a JASCO A-320 instrument. ${ }^{1} \mathrm{H}-\mathrm{NMR}$ spectra were recorded on Bruker AC-300 and AMX-500 MHz instrument, while ${ }^{13} \mathrm{C}-\mathrm{NMR}$ spectra were recorded on same instrument at 100 and $150 \mathrm{MHz} .{ }^{1} \mathrm{H}-\mathrm{NMR}$ and ${ }^{13} \mathrm{C}-\mathrm{NMR}$ chemical shifts are reported in $\delta(\mathrm{ppm})$ and coupling constant values $(J)$ were measured in Hz. The EI MS spectra were recorded on mass spectrometers (Varian MAT 311A and MAT 312). FAB MS and HREI MS experiments were performed on Jeol HX 110 mass spectrometer. ESI experiments were performed on QSTAR XL (Applied Biosystems). The ion peaks are presented in $m / z(\%)$. Precoated silica gel TLC plates (E. Merk, $\mathrm{F}_{254}$ ) were used for checking purity of compounds and spots were visualized under UV light and by spraying with ceric sulphate $\left(10 \% \mathrm{H}_{2} \mathrm{SO}_{4}\right)$.

\section{Extraction and Isolation}

The aerial parts of $O$. wightiana, were collected from Kavre, Nepal, in August 2005 at the altitudes of $1,600 \mathrm{~m}$ to $1,700 \mathrm{~m}$ and identified by comparison with the authentic herbarium specimen at the National Herbarium Laboratory, Department of Plant Resources, Godawari, Nepal. The air dried aerial part of $O$. wightiana $(6.3 \mathrm{Kg})$ was extracted with $80 \%$ ethanol-water $(25 \mathrm{~L})$ for three times. The concentrated ethanolic extract, $970.4 \mathrm{~g}$ was obtained after evaporating the solvent. The crude extract was then dissolved in distilled water $(8 \mathrm{~L})$ and aqueous layer was further subjected to solvent-solvent extraction. The aqueous layer was extracted with $n$-hexane, dichloromethane (at neutral, $\mathrm{pH} 3-4$, and $\mathrm{pH} 9-10$ ), ethyl acetate and $n$-butanol, simultaneously. The neutral dichloromethane fraction $(28.0 \mathrm{~g})$ was further column chromatographed for isolation of pure compounds. From silica gel column chromatography, eluting the neutral dichloromethane fraction, with $n$-hexane/ acetone system in a gradient way, $( \pm)$ lyoniresinol (1), ( \pm )syringaresinol (2) 5,5'-dimethoxylariciresinol (3), and 5-methoxylariciresinol (4) were seperated.

\section{( \pm ) Lyoniresinol (1)}

Amorphous solid, mp 193-194 ${ }^{\circ} \mathrm{C}$, UV (EtOH) $\lambda_{\max } \mathrm{nm}(\log \varepsilon): 281\left(3.75 \times 10^{3}\right), 275\left(3.75 \times 10^{3}\right)$. IR $\left(\mathrm{CHCl}_{3}\right) v_{\max } \mathrm{cm}^{-1}: 3410,1612,1515,1502,1455,1320,1218,1110$. EI MS $\mathrm{m} / \mathrm{z}$ (rel. int. \%): 420 (12), 330 (3), 208 (100), 182 (32), 153 (47), 137 (42), 93 (35) ${ }^{1} \mathrm{H}-$ and ${ }^{13} \mathrm{C}-\mathrm{NMR}, \delta$ ppm (300 and $150 \mathrm{MHz}$, $\left.\mathrm{CHCl}_{3}\right):{ }^{1} \mathrm{H}-\mathrm{NMR}: \delta_{\mathrm{H}} 4.31\left(\mathrm{~d}, J_{2,1}=6.0 \mathrm{~Hz}, \mathrm{H}-1\right), 1.95(\mathrm{~m}, \mathrm{H}-2), 3.53(\mathrm{~m}, \mathrm{H}-2 \mathrm{a}), 1.63(\mathrm{~m}, \mathrm{H}-3), 3.48(\mathrm{~m}$, $\mathrm{H}-3 \mathrm{a}), 2.72\left(\mathrm{dd}, J_{4 \mathrm{c}, 4 \mathrm{~b}}=15.0 \mathrm{~Hz}, J_{4 \mathrm{a}, 3}=5.0 \mathrm{~Hz}, \mathrm{H}_{\mathrm{a}}-4\right), 2.60\left(\mathrm{dd}, J_{4 \mathrm{c}, 4 \mathrm{~b}}=15.0 \mathrm{~Hz}, J_{4 \mathrm{~b}, 3}=7.5 \mathrm{~Hz}, \mathrm{H}_{\mathrm{b}}-4\right), 6.70$ (s, H-5), 6.37 (s, H-2' or H-6'), 3.84 (s, OMe-6), 3.84 (s, OMe-8) and 3.72 (s, OMe-3' or 5'); ${ }^{13} \mathrm{C}-\mathrm{NMR}$ : $\delta_{\mathrm{C}} 42.3(\mathrm{C}-1), 48.8(\mathrm{C}-2), 64.1(\mathrm{C}-2 \mathrm{a}), 40.8$ (C-3), 66.7 (C-3a), 33.5 (C-4), $130.2(\mathrm{C}-4 \mathrm{a}), 107.7$ (C-5), 138.8 (C-6), 148.6 (C-7), 147.6 (C-8), 126.2 (C-8a), 139.3 (C-1'), 106.8 (C-2' or 6'), 149.0 (C-3' or 5'), 134.4 (C-4'), 56.6 (OMe-6), 56.6 (OMe-8), 56.7 (OMe-3'or -5').

\section{(士) Syringaresinol (2)}

White solid, mp 170-173 ${ }^{\circ} \mathrm{C}$, UV (MeOH) $\lambda_{\max } \mathrm{nm}(\log \varepsilon): 217\left(1.65 \times 10^{4}\right), 237\left(1.12 \times 10^{4}\right), 273$ (2.09x 10 ${ }^{3}$ ), IR (KBr film) $v_{\max } \mathrm{cm}^{-1}: 3440,1615,1519$. EI MS $\mathrm{m} / z$ (rel. int. \%): 182 (58), 167 (33), 154 (10), 123 (10), 111 (14), 91 (24), 57 (100). ${ }^{1} \mathrm{H}$ - and ${ }^{13} \mathrm{C}-\mathrm{NMR}, \delta \mathrm{ppm}\left(300\right.$ and $\left.125 \mathrm{MHz}, \mathrm{CHCl}_{3}\right):{ }^{1} \mathrm{H}-$ NMR: $\delta_{\mathrm{H}} 6.56\left(\mathrm{~s}, \mathrm{H}-2\right.$ or H-6), $4.71\left(\mathrm{~d}, J_{8,7}=4.0 \mathrm{~Hz}, \mathrm{H}-7\right), 3.07(\mathrm{~m}, \mathrm{H}-8), 4.26\left(\mathrm{dd}, J_{9 \mathrm{a}, 9 \mathrm{~b}}=9.0 \mathrm{~Hz}, J_{9 \mathrm{a}, 8}=\right.$ $\left.6.7 \mathrm{~Hz}, \mathrm{H}_{\mathrm{a}}-9\right), 3.90$ (overlapped) and 3.87 (s, OMe-3 or OMe-5); ${ }^{13} \mathrm{C}-\mathrm{NMR}: \delta_{\mathrm{C}} 132.0(\mathrm{C}-1), 102.6(\mathrm{C}-2$ or 6), 134.2 (C-3 or 5), 147.1 (C-4), 86.0 (C-7), 54.3 (C-8), 71.7 (C-9), 56.3 (OMe-3 or OMe-5).

\section{5,5'-Dimethoxylariciresinol (3)}

Colorless crystalline substance, mp $124-126{ }^{\circ} \mathrm{C},[\alpha]_{\mathrm{D}}{ }^{25}:+5^{\circ}(c 0.27, \mathrm{MeOH}), \mathrm{UV}\left(\mathrm{CHCl}_{3}\right) \lambda_{\max } \mathrm{nm}$ (log $\varepsilon): 235$ (4.08), 272 (3.64), 280 (3.60). IR $\left(\mathrm{CHCl}_{3}\right) v_{\max } \mathrm{cm}^{-1}: 3420,1610,1520$. EI MS $\mathrm{m} / z$ (rel. int. $\%): 420$ (35), 388 (3), 221 (14), 181 (38), 167 (100), 123 (19). ${ }^{1} \mathrm{H}-$ and ${ }^{13} \mathrm{C}-\mathrm{NMR}, \delta$ ppm (300 and 150 MHz, $\mathrm{CHCl}_{3}$ ): ${ }^{1} \mathrm{H}-\mathrm{NMR}: \delta_{\mathrm{H}} 6.35$ (s, H-2 or H-6), 2.36 (dd, $\left.J_{7 \mathrm{a}, \mathrm{b}}=14.0 \mathrm{~Hz}, J_{8,7 \mathrm{a}}=7.0 \mathrm{~Hz}, \mathrm{H}_{\mathrm{a}}-7\right), 2.85$ (dd, $\left.J_{7 \mathrm{a}, 7 \mathrm{~b}}=14.0 \mathrm{~Hz}, J_{8,7 \mathrm{~b}}=5.0 \mathrm{~Hz}, \mathrm{H}_{\mathrm{b}}-7\right), 2.64(\mathrm{~m}, \mathrm{H}-8), 3.96\left(\mathrm{dd}, J_{9 \mathrm{a}, 9 \mathrm{~b}}=8.4 \mathrm{~Hz}, J_{9 \mathrm{a}, 8}=6.5 \mathrm{~Hz}, \mathrm{H}_{\mathrm{a}}-9\right), 3.65$ (dd, $\left.J_{9 \mathrm{a}, 9 \mathrm{~b}}=8.4 \mathrm{~Hz}, J_{9 \mathrm{~b}, 8}=6.5 \mathrm{~Hz}, \mathrm{H}_{\mathrm{b}}-9\right), 6.50\left(\mathrm{~s}, \mathrm{H}-2^{\prime}\right.$ 'or H-6'), 4.71 (d, $\left.J_{8}{ }^{\prime}, 7^{\prime}=6.4 \mathrm{~Hz}, \mathrm{H}-7^{\prime}\right), 2.31$ (m, H- 
$8^{\prime}$ ), 3.83, 3.37 (overlapped, H-9'), 3.81 (s, OMe-3 or -5 ) and 3.79 (s, OMe-3' or 5'); ${ }^{13} \mathrm{C}-\mathrm{NMR}$ : $\delta_{\mathrm{C}} 131.3$ (C-1), 105.2 (C-2 or C-6), 147.0 (C-3 or C-5), 133.8 (C-4), 33.5 (C-7), 42.2 (C-8), 72.2 (C-9), 131.3 (C1'), 102.7 (C-2' or C-6'), 147.0 (C-3' or C-5'), 133.8 (C-4'), 82.2 (C-7'), 52.5 (C-8'), 60.3 (C-9'), 56.1 (OMe-3 or -5$), 56.1\left(\mathrm{OMe}-3^{\prime}\right.$ or $\left.5^{\prime}\right)$.

\section{5-Methoxylariciresinol (4)}

Gummy substance, $[\alpha]_{\mathrm{D}}{ }^{25}:+0.3^{\circ}\left(c 0.33, \mathrm{Me}_{2} \mathrm{CO}\right), \mathrm{UV}\left(\mathrm{CHCl}_{3}\right) \lambda_{\max } \mathrm{nm}(\log \varepsilon): 230$ (4.71), 281 (4.19). IR $\left(\mathrm{CHCl}_{3}\right) v_{\max } \mathrm{cm}^{-1}: 3432,1614,1517$. EI MS m/z (rel. int. \%): 390 (100), 210 (14), 181 (31), 167 (24), 137 (88), 122 (32). ${ }^{1} \mathrm{H}$ - and ${ }^{13} \mathrm{C}-\mathrm{NMR}, \delta \mathrm{ppm}\left(300\right.$ and $\left.150 \mathrm{MHz}, \mathrm{CHCl}_{3}\right):{ }^{1} \mathrm{H}-\mathrm{NMR}: \delta_{\mathrm{H}} 6.66(\mathrm{~s}$, $\mathrm{H}-2), 6.83\left(\mathrm{~d}, J_{6,5}=8.5 \mathrm{~Hz}, \mathrm{H}-5\right), 6.68\left(\mathrm{~d}, J_{6,5}=8.5 \mathrm{~Hz}, \mathrm{H}-6\right), 2.90\left(\mathrm{dd}, J_{7 \mathrm{a}, 7 \mathrm{~b}}=13.5 \mathrm{~Hz}, J_{8,7 \mathrm{a}}=5.1 \mathrm{~Hz}, \mathrm{H}_{\mathrm{a}^{-}}\right.$ 7), $2.53\left(\mathrm{dd}, J_{7 \mathrm{a}, 7 \mathrm{~b}}=13.5 \mathrm{~Hz}, J_{8,7 \mathrm{~b}}=10.6 \mathrm{~Hz}, \mathrm{H}_{\mathrm{b}}-7\right), 2.72(\mathrm{~m}, \mathrm{H}-8), 3.75\left(\mathrm{dd}, J_{9 \mathrm{a}, 9 \mathrm{~b}}=8.5 \mathrm{~Hz}, J_{9 \mathrm{a}, 8}=6.2 \mathrm{~Hz}\right.$, $\left.\mathrm{H}_{\mathrm{a}}-9\right), 4.04\left(\mathrm{dd}, J_{9 \mathrm{a}, 9 \mathrm{~b}}=8.5 \mathrm{~Hz}, J_{9 \mathrm{~b}, 8}=6.2 \mathrm{~Hz}, \mathrm{H}_{\mathrm{b}}-9\right), 6.54\left(\mathrm{~s}, \mathrm{H}-2\right.$ ' or H-6'), 4.79 (d, $\left.J_{7}{ }^{\prime}, 8^{\prime}=6.3 \mathrm{~Hz}, \mathrm{H}-7^{\prime}\right)$, 2.39 (m, H-8'), 3.92, 3.89 (overlapped, H-9'), 3.86 (s, OMe-3) and 3.85 (s, OMe-3' or $-5^{\prime}$ ); ${ }^{13} \mathrm{C}-\mathrm{NMR}$ : $\delta_{\mathrm{C}}$ 132.2 (C-1), 111.1 (C-2), 146.5 (C-3), 144.0 (C-4), 114.4 (C-5), 121.1 (C-6), 33.3 (C-7), 42.3 (C-8), 72.9 (C-9), $134.0\left(\mathrm{C}^{\prime} 1^{\prime}\right), 102.4\left(\mathrm{C}-2^{\prime}\right.$ ' or 6'), 147.0 (C-3' or 5'), 134.0 (C-4'), 83.0 (C-7'), 52.6 (C-8'), 61.0 (C9'), 55.9 (OMe-3), 56.4 (OMe-3' or 5').

\section{Results and Discussion}

The lignans derivatives, $( \pm$ ) Lyoniresinol (1), $( \pm$ ) Syringaresinol (2) 5,5'-Dimethoxylariciresinol (3), and 5-Methoxylariciresinol (4), were isolated from the neutral dichloromethane extract (data presented in experimental section). Lignans are first time reported from the genus Osyris (Fig. 1). ( \pm ) Lyoniresinol (1) was isolated as a white amorphous solid. The ${ }^{13} \mathrm{C}$ NMR (broad-band decoupled and DEPT) spectra of compound 1 showed total 22 carbon signals, including 4 methyl, 3 methylene, 6 methine and 9 quaternary carbons. The EI MS showed the molecular ion peak at $\mathrm{m} / \mathrm{z} 420.0$ which corresponds to molecular formula $\mathrm{C}_{22} \mathrm{H}_{28} \mathrm{O}_{8}$. The IR spectrum revealed the presence of hydroxyl group $\left(3410 \mathrm{~cm}^{-1}\right)$. The downfield multiplets in functional group region of ${ }^{1} \mathrm{H}$ NMR at $\delta_{\mathrm{H}} 3.53(\mathrm{H}-2 \mathrm{a})$ and $3.48(\mathrm{H}-3 \mathrm{a})$ and the signals at $\delta_{\mathrm{C}}$ 64.1 (C-2a) and 66.7 (C-3a) in ${ }^{13} \mathrm{C}$ NMR further confirms the presence of hydroxyl groups. The UV spectrum showed typical absorption bands at $\lambda_{\max } 275-281 \mathrm{~nm}$. The downfield singlet in aromatic region of ${ }^{1} \mathrm{H}$ NMR at $\delta_{\mathrm{H}} 6.37$ and 6.70 was assigned for H-2' (or H-6') and $\mathrm{H}-5$, respectively. The downfield signals at $\delta_{\mathrm{C}} 130.2(\mathrm{C}-4 \mathrm{a}), 107.7$ (C-5), 138.8 (C-6), 148.6 (C-7), 147.6 (C-8), 126.2 (C-8a), 139.3 (C-1'), $106.8\left(\mathrm{C}^{2}{ }^{\prime}\right.$ or $\left.6^{\prime}\right), 149.0\left(\mathrm{C}^{\prime} 3^{\prime}\right.$ ' or 5') and $134.4\left(\mathrm{C}^{\prime} 4^{\prime}\right)$ gave evidence for the presence of aromatic ring systems. The methine doublet at $\delta_{\mathrm{H}} 4.31(J=6.0 \mathrm{~Hz})$ was assigned to $\mathrm{H}-1$. The C-4 diastereotopic methylene protons appeared as the double doublets at $\delta_{\mathrm{H}} 2.72(J=15.0$ and $5.0 \mathrm{~Hz})$ and $2.60(J=15.0$ and $7.5 \mathrm{~Hz})$ due to germinal and vicinal coupling. The two multiplets at upfield region appeared at $\delta_{\mathrm{H}}$ $1.95(\mathrm{H}-2)$ and $1.63(\mathrm{H}-3)$. The overlapping singlets at $\delta_{\mathrm{H}} 3.84$ and 3.72 were assigned to methoxyl groups. On detailed examination of NMR spectra, the structure of compound $\mathbf{1}$ was determined and identical to reported data. ${ }^{15}$

( \pm ) Syringaresinol (2) was obtained as colorless crystals. The UV spectrum showed absorption bands at $\lambda_{\max } 217,237$ and $273 \mathrm{~nm}$ while the IR spectrum showed absorption at $v_{\max } 3340(\mathrm{OH})$ and 1615 and $1519(\mathrm{C}=\mathrm{C}) \mathrm{cm}^{-1}$. The EI MS did not show the molecular ion peak, but a prominent peak appeared at $\mathrm{m} / \mathrm{z}$ 182.0. The molecular mass was deduced to be 418.0 amu from the $\mathrm{FAB}^{+} \mathrm{ve}(\mathrm{m} / \mathrm{z} 419)$ and $\mathrm{FAB}^{-} \mathrm{ve}(\mathrm{m} / \mathrm{z}$ 417) MS. Furthermore ESI MS (with TOF MS, $m / z$ 419.21) were carried out to confirm the molecular ion. Compound $\mathbf{2}$ was acetylated by acetic anhydride in pyridine at room temperature to afford the acetate derivative. The ESI MS of the acetyl derivative of compound 2 showed characteristic losses of acetyl and water molecule from the $\left[\mathrm{M}^{+}-\mathrm{H}\right]$ of acetyl derivative (at $\mathrm{m} / \mathrm{z}$ 503.18). The ${ }^{1} \mathrm{H}$ NMR and ${ }^{13} \mathrm{C}$ NMR of compound 2 showed characteristic signals for symmetrical molecule. The 4 signals were observed at $\delta_{\mathrm{C}}$ 132.0 (C-1), 102.6 (C-2 or 6), 134.2 (C-3 or 5) and147.1 (C-4) for aromatic ring carbons. The downfield 
<smiles>COc1cc([C@@H]2c3c(cc(OC)c(O)c3OC)C[C@@H](CO)[C@H]2CO)cc(OC)c1O</smiles>

( \pm ) Lyoniresinol<smiles>COc1cc(C[C@@H]2CO[C@@H](c3cc(OC)c(O)c(OC)c3)[C@H]2CO)cc(OC)c1O</smiles>

5,5'-Dimethoxylariciresinol<smiles>COc1cc([C@@H]2[C@@H]3CO[C@@H](c4cc(OC)c(O)c(OC)c4)[C@@H]3CO[C@H]2c2cc(OC)c(OC)c(OC)c2)cc(OC)c1O</smiles>

( \pm ) syringaresinol<smiles>COc1cc(C[C@@H]2CO[C@@H](c3cc(OC)c(O)c(OC)c3)[C@H]2CO)ccc1O</smiles>

5'-Methoxylariciresinol

Figure 1: Structures of lignans

singlet in aromatic region at $\delta_{\mathrm{H}} 6.56$ was assigned to $\mathrm{H}-2$ or $\mathrm{H}-6$. The downfield protons at $\delta_{\mathrm{H}} 4.26$ (dd, $J$ $=9.0$ and $6.7 \mathrm{~Hz}$ ) and 3.90 (overlapped) were assigned to C-9 diastereotopic protons. By comparing the NMR data, the compound 2 was confirmed as $( \pm)$ Syringaresinol. ${ }^{16}$

5,5'-Dimethoxylariciresinol (3) was isolated as colorless crystals. The EI MS showed the molecular ion peak at $m / z$ 420. The ${ }^{13} \mathrm{C}$ NMR spectra (broad band decoupled and DEPT) of compound 3 showed a total of 22 carbons signals, including 4 methyl, 3 methylene, 7 methine and 8 quartenary carbons. The signals at $\delta_{\mathrm{H}} 2.36(\mathrm{dd}, J=14.0$ and $7.0 \mathrm{~Hz})$ and $2.85(\mathrm{dd}, J=14.0$ and $5.0 \mathrm{~Hz})$ were assigned to geminal protons of $\mathrm{C}-7$ which were different from compound 2. It indicated the ring opening at C-7. The multiplets at $\delta_{\mathrm{H}} 2.64(J \approx 6.5 \mathrm{~Hz}, \mathrm{H}-8)$ and $2.31(\mathrm{H}-8$ ') indicated that $\mathrm{H}-8$ and $\mathrm{H}-8$ ' were in cis disposition. The comparision of spectral data with literature indicates that the compound was 5,5'dimethoxylariciresinol. ${ }^{17}$

5-Methoxylariciresinol (4) was obtained as a resin. The EI MS exhibited a molecular ion peak at $\mathrm{m} / \mathrm{z}$ 390.0. It differs from compound three by loss of methoxy group at C-5 position. The doublets at $\delta_{\mathrm{H}} 6.83$ $(\mathrm{d}, J=8.5 \mathrm{~Hz})$ and $6.68(\mathrm{~d}, J=9.5 \mathrm{~Hz})$ were observed for $\mathrm{H}-5$ and $\mathrm{H}-6$, respectively, due to vicinal 
coupling. It showed similar NMR pattern to that of compound $\mathbf{3}$ and from the careful analysis of UV, IR, EI MS and ${ }^{1} \mathrm{H}$ and ${ }^{13} \mathrm{C}$-NMR data, it is identical to 5 '-methoxylariciresinol. ${ }^{18}$

\section{Conclusions}

The structures of lignans class of compounds (1-4) were elucidated by detail analysis of various spectroscopic techniques and comparing its spectral data in the literature. It is the first report of lignans in Osyris and the results indicate the possible chemotaxonomic significance of the occurrence of lignans in santalaceae.

\section{Acknowledgements}

The ICCBS fellowship from HEJ Research Institute of Chemistry, Pakistan is gratefully acknowledged for financial support to this research work.

\section{References}

1. Z. S. Shu, Flora of China, Science Press (Beijing) and Missouri Botanical Garden Press (England), 2003.

2. N. P. Manandhar, Plants and People of Nepal, Timber Press Inc., Portland, Oregan, 2002.

3. M. Osujih, J. R. Soc. Health, 1993, 113, 190-4.

4. N. K. Bhattarai, Int. J. Crude Drug Res., 1990, 28, 225-231.

5. I. Shrestha and N. Joshi, Int. J. Pharmacog., 1993, 31, 130-134.

6. F. Demirici and K. H. C., Baser, Flavour. Fragr. J., 2004, 19, $72-73$.

7. G. M. Woldemichael and M. Wink, Biochem. Syst. Ecol., 2002, 30, 139-149.

8. A. T. Kreipl and W. A. Konig, Phytochemistry, 2004, 65, 2045-2049.

9. E. M. O. Yeboah, R. R. T. Majinda, A. Kadziola and A. Muller, J. Nat. Prod., 2010, 73, 11511155.

10. F. Le Scao, G. Faugeras and R. R. Paris, Plantes Medicinales et Phytotherapie, 1972, 24, 152-157.

11. T. Iwashina, A. L. S. Jose and J. Kitajima, Biochem. Sys. Ecol., 2008, 36, 146-147.

12. L. Pepe and M. Castellani, Boll. Chim. Farm., 1969, 108, 546.

13. Izhaki, J. Chem. Ecol., 1993, 19, 2605.

14. H. I. Jaber, I. M. Mosleh, A. Mallough, O. M. Abusalim and M. H. Abuzarga, J. Asian Nat. Prod. Res., 2010, 12, 814-820.

15. K. Freudenberg and K. Weinges, Tetrahendron Lett., 1959, 17, 19.

16. F. Abe and T. Yamauchi, Phytochemistry, 1988, 27, 575-577.

17. F. Abe and T. Yamauchi, Phytochemistry, 1989, 28, 1737-1741.

18. Y. D. Chang, H. P. Charles, J. J. M. Pezzuto, A. D. Kinghorn and N. R. Farnsworth, J. Nat. Prod., 1986, 49, 706-709. 